\title{
FOGYASZTÓI MOTIVÁCIÓS VIZSGÁLATOK A DVSC LABDARÚGÓ CSAPATÁNAK BÉRLETESEI KÖRÉBEN
}

\author{
CONSUMER MOTIVATIONAL RESEARCH AMONG DVSC SOCCER CLUB'S SEASON TICKET \\ OWNERS
}

\author{
Komáromi Dominika Anna ${ }^{1}$, Bácsné Bába Éva ${ }^{1}$ \\ ${ }^{1}$ Debreceni Egyetem, Gazdaságtudományi Kar, Sportgazdasági és -Menedzsment Intézet
}

\begin{abstract}
Összefoglaló
Jelen tanulmányban a DVSC labdarúgó mérkőzéseit bérlettel látogató szurkolók szocio-demográfiai jellemzőit és összetételét vizsgáltuk, illetve a debreceni közönség sportfogyasztását meghatározó motivációs tényezőket mértük fel. A szakirodalmi források feldolgozása után elkészítettük a mérőeszközt, mely szocio-demográfiai, mérkőzéslátogatási szokásokkal, létesítménnyel és szolgáltatásokkal, illetve belépókkel, jegyárakkal kapcsolatos kérdéseket tartalmazott. Az adatokat személyes és online formában is gyüjtöttük, így összesen 49 fös mintát vizsgáltunk. Az eredmények kiértékelése során kiderült, hogy a DVSC bérlettel rendelkező szurkolói úgy a csapat sikerét, mint kudarcát sajátjukként élik meg. Összességében megállapítható, hogy az állandó belépővel rendelkezôk biztos résztvevőket jelentenek, számuk növelése kulcsfontosságú a klub számára, mely a csapat és a szurkoló közötti kötelék létrehozásával és erősítésével valósítható meg.
\end{abstract}

Kulcsszavak: labdarúgó klub, bérletesek, sport fogyasztás, fogyasztói motiváció, mérkőzés látogatási szokások

\begin{abstract}
In this research, we investigated socio-demographic attributes and structure of DVSC Soccer Club's season ticket owners and measured the motivational factors determining the sports consumption of Debrecen's audience. After the literature review, we developed a tool for the measurement of the following factors: socio-demographic and match visiting habits, facilities and service, tickets and prices. We collected the data of the 49 samples online and through personal meetings. By evaluating the results, it became clear that fans of DVSC with season tickets experience the team's success and failure as their own. Overall, it can be stated that those who have permanent entrants are surely visiting the matches. The growth of the season ticket owners is a key question for the club, which is determined by the creation and improvement of the club-fan bond.
\end{abstract}

Keywords: soccer club, season ticket owners, sports consumption, consumer motivation, match visiting habits

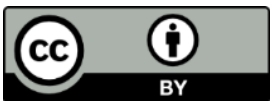




\section{BEVEZETÉS}

Napjainkban a labdarúgás jelentős tömegeket mozgat meg, hazánkban még ma is az egyik legnézettebb sportágak közé tartozik. A magyar labdarúgó bajnokság mérkőzésein ugyanakkor az alacsony nézőszámok problémájával találkozunk, mely a debreceni futballnak otthont adó Nagyerdei Stadion lelátóit sem kerülte el.

A DVSC NB1-es férfi labdarúgó csapatának mérkőzéseit gyerekkorom óta bérletesként látogatom, egyetemi tanulmányaim alatt pedig betekintést nyerhettem a fogyasztói magatartás vizsgálatok publikált eredményeibe. Ezek adtak indíttatást arra, hogy egy speciális fogyasztói csoport, a DVSC labdarúgó csapat állandó belépővel rendelkező nézőit tanulmányozzam.

A bérletes szurkolók általában jelentős hányadát képezik a közönségnek, az összecsapásokat rendszeresen látogatók közé sorolhatóak, így felmérésük, jellemzőik és motivációik megismerése mérvadó a nézőszámok emelésének érdekében.

A megfelelő szakirodalmi források összegyűjtése és feldolgozása után a DVSC magyar első osztályban szereplő labdarúgó klub bérleteseinek összetétel és motiváció vizsgálatára alkalmas mérőeszközömet kívánom elkészíteni. Célom, hogy feltárjam a különböző korú, szociális helyzetű, képzettségű szurkolók mérkőzéslátogatási szokásait, ami alapján javaslatok fogalmazhatóak meg az állandó belépővel rendelkezők számának bővítésére.

\section{SZAKIRODALMI ÁTTEKINTÉS}

\section{A SPORTFOGYASZTÁS}

\section{A sporttermékek fogyasztása}

Napjainkban a sport egyre fontosabb részét képezi mindennapi életünknek, a különböző infrastrukturális fejlesztéseknek köszönhetően több lehetőségünk van sportolni, hazánk pedig jelentős nemzetközi sporteseményeknek adhat otthont.

A sport, mint termék rendelkezik kereslettel és kínálattal, és hasonlóan bármilyen másik jószághoz, hasznot és megoldást jelent a fogyasztók részére (NEULINGER, 2007).

A sporttermékek közé a szakirodalom a következő elemeket sorolja (MULLIN ET AL. 1993; HOFFMANN, 2000; SHANK, 2002; NEULINGER, 2007) : tárgyiasult elemek; szolgáltatás; személy; szervezet; hely, helyszín; eszme, imázs.

Így elmondhatjuk a fentiek alapján, hogy egy sporttermék állhat egy elemből is, de lehet akár több elem komplex szerveződése. Továbbá ezeknek a termékeknek a jellemzője, hogy megfogható és megfoghatatlan összetevőkkel is rendelkeznek, megfogható termék 
például a belépőjegy, vagy valamilyen sporteszköz, megfoghatatlan pedig a klub, az imázs, a sportesemény és az általa nyújtott élmény lehet (NEULINGER, 2007; SZABÓ, 2009). Tehát a sporttermékek iránti kereslet, azaz a sportfogyasztók igényei, szükségletei ilyen tárgyiasult és nem tárgyiasult elemekben határozhatóak meg.

A sportfogyasztás megvalósulhat aktív és passzív formában is, aktív fogyasztást jelent valamilyen sporttevékenység végzése, passzív formája pedig sportesemény, mérkőzésen nézőként való részvétel, vagy ezen események egyéb módon történő követése (NEULINGER, 2007; SZABÓ, 2009). Esetünkben a sportfogyasztás passzív formájára koncentrálunk, mely tehát különböző sporttal kapcsolatos rendezvények megtekintését jelenti. Neulinger (2007) alapján a sportesemény: „Magában foglalja a sportjátszmákat, mérkőzéseket, a sportcsarnokot (helyszínt), a sportolókkal, sportsztárokkal együtt".

Nézői sportfogyasztás tekintetében elmondhatjuk, hogy ebben az esetben a megtekintett vagy megtekinteni kívánt esemény által nyújtott élmény az, ami miatt bekövetkezik a fogyasztás.

Természetesen egy sportesemény nem csak az általa nyújtott élményből és izgalomból áll, mindez kiegészül többek között az esemény szereplőivel, a szervezőkkel, a helyszínül szolgáló létesítménnyel, és ezek együttesen képezik azt a szolgáltatást, szolgáltatáscsomagot, amelyet a sportfogyasztók megvásárolnak (NEULINGER, 2007). A szervezők legfontosabb feladata tehát, hogy minden szinten kielégítsék és akár felülmúlják a fogyasztók igényeit és elvárásait, és összességében olyan élményt nyújtsanak - minőségben és színvonalban egyaránt -, amely a későbbiekben újabb fogyasztást idézhet elő a nézők körében. A sportszervezetek számára egy olyan érték megalkotása a cél, mely ösztönzi a vásárlást, jelentse ez akár a játékosok sportteljesítményét, a létesítmény állapotát, a szolgáltatások minőségét is.

\section{A sportfogyasztók köre}

Neulinger (2007) szerint a sporttermékek iránti keresletet a piacon az alábbi szereplók alkotják:

- az egyén, aki sporttevékenységet végez vagy nézőként vesz részt,

- a szponzorok és támogatók, akik gazdaságilag vagy egyéb hozzájárulással finanszírozzák a múködést,

- és a sporteseményeket közvetíteni kívánó média.

A keresletnek jelen helyzetben azt a részét vizsgáljuk, melynek igénye élőben, helyszíni nézőként megtekinteni az adott sporteseményt, esetünkben labdarúgó mérkőzést. A sportfogyasztók tipizálása, szegmentálása kiemelten fontos annak érdekében, hogy a szervezetek meg tudják határozni marketing tevékenységüket, segít az árképzésben, a termékek piaci elhelyezésében és segít a különböző szegmensek eltérő igényeinek 
feltérképezésében, ezen szükségletek minél hatékonyabb kielégítésének céljából (Stewart et al. 2003).

A legelső duális tipológiák egyikét Clarke (1978) hozta létre, aki megkülönböztette a nézők két csoportját: a genuine szurkolók azok, akik a futballmérkőzéseket közösségi élményként élik meg, ezzel szemben a corporate az a csoport, akik a mérkőzéseket hétvégi kikapcsolódásnak, szórakozásnak tekintik. Lewis (2009) szintén duális megközelítése szerint, amely az identifikáción alapult, a civic csoportba tartozók azok, akik a várossal, a symbolic pedig azokat jelenti, akik magával a csapattal azonosulnak (Stewart et al. 2003). Smith és Stewart (1999) a mérkőzéseket rendszeresen látogató, a csapathoz hűséges, annak játékosaival és hagyományaival azonosuló szurkolókat passionate partisans -nek nevezte. A champ followers azokat jelenti, akik kevésbé fanatikusak, és csak csapatuk jó szereplésekor jelennek meg. A harmadik csoport a reclusive partisans, akik erősen elköteleződtek a csapathoz, de ritkán látogatják a mérkőzéseket (STEWART et al. 2003). A sportszervezetek számára elengedhetetlen célközönségük megismerése és megfelelő szegmentálása (BÁCSNÉ et al., 2019; BALOGH et al., 2019c) annak érdekében, hogy gazdaságilag megfelelően tudjanak működni, termékeiket a megfelelő helyen és időben, egy adott szegmens számára értékesíteni tudják. A szurkolók rendkívül széles köre miatt csoportosításuk nehéz feladat, a legtöbb tipizálás a hűségen, az azonosuláson és ezek különböző erősségein alapszik.

\section{A magyar labdarúgás}

Hazánkban a labdarúgásnak jelentős hagyománya és történelme van. Bár nem ez a legtöbb sikert hozó sportág, kijelenthető, hogy napjainkban is talán a legnagyobb népszerűségnek örvend országunkban és a világban is.

Az elmúlt években több, NB1-es labdarúgó csapat számára is új stadion épült, ugyanakkor általánosan a nézőszámok csökkenéséről lehet hallani. A magyarfutball.hu adatai alapján ezt az állítást meg lehet cáfolni, hiszen az elmúlt évek statisztikái alapján az élvonalbeli labdarúgó mérkőzések átlagos nézőszámai szezonról szezonra növekedtek, viszont az kijelenthető, hogy a stadionok befogadóképességéhez és más első osztályú bajnokságokhoz képest ezek a számok valóban alacsonyak (BALOGH et al., 2019b).

Az előző, azaz a 2019/2020-as idényben az NB1-ben 3300, a DVSC hazai mérkőzésein 3547 volt az átlag, a DVSC adatai az elmúlt 20 évben szinte mindig a bajnokság nézőszámainak átlagai felett voltak (MAGYARFUTBALL, 2020).

A magyarfutball.hu statisztikái azt mutatják, hogy a DVSC hazai környezetben megrendezett mérkőzései közül a 2019/2020-as szezonban az FTC elleni eredményezte a legnagyobb, számszerit 7002 fős nézősereget. A legmagasabb nézőszámokat továbbá a Paksi FC, az MTK és a DVTK elleni összecsapások hozták, ezzel is mutatva, hogy a hasonló 
szintű, illetve a nagy múltú fôvárosi csapatok keltik a legnagyobb érdeklődést a szurkolók körében.

A közönség jelentős részét alkotják és többnyire állandó fogyasztást biztosítanak azok, akik bérlettel, azaz egész szezonra szóló érvényes belépőjeggyel rendelkeznek. A DVSC futballcsapatának körülbelül 3000 bérletes szurkolója van, ennek a számadatnak a bővítése fontos célja a klubnak, hiszen ők biztos bevételi forrást és folyamatos részvételt garantálhatnak hazai környezetben.

A bérletesek fontosságát a DVSC is felismerte, hiszen az ilyen belépővel rendelkező nézőinek különböző kedvezményeket ad, ilyen például a mérkőzések napján ingyenes utazás a DKV járataival, engedmények az Állatkertbe és az Aquaticumba szóló jegyek árából, illetve kedvezően kialakított családi, diák és nyugdíjas bérletárak (DVSC, 2020). A DVSC a LokomotívBlog (2019) összefoglalója alapján a magyar NB1-ben szereplő klubok közül az első három, legkedvezőbb bérletárakat alkalmazók körébe tartozik. A legjobban megfizethető szezonális belépők tekintetében csak az Újpest FC és a Mezőkövesd Zsóry FC előzi meg, ezzel is alátámasztva azt, hogy a klub erőteljes hangsúlyt fektet a bérletesek számának növelésére, mind az árak kialakítását figyelembe véve, mind pedig a bérletekkel járó kedvezmények vonatkozásában.

\section{Motivációs skálák}

Annak érdekében, hogy azon sportfogyasztók számát növelni tudjuk, akik a helyszínen, a nézőtéren tekintik meg az adott sporteseményt, azaz a DVSC labdarúgó csapatának hazai mérkőzéseit, meg kell vizsgálnunk, hogy melyek azok a motivációs tényezők, amelyek kiváltják a fogyasztásnak ezen típusát, a különböző motivációs skálák pedig ehhez nyújtanak nekünk segítséget.

A skálák közül a 2017-ben validált magyar nyelvű SPEEDE-H skálát, a nézőtéri sportfogyasztás motivációit mérő eszközt (BALOGH et al., 2019a) választottuk, mely az eredeti SPEED nyomán készült el, de olyan változtatásokkal egészült ki, amelyek lehetővé teszik magyarországi alkalmazását. A SPEEDE-H skála hat faktort tartalmaz, minden faktorhoz két item tartozik, így összesen tizenkét kérdés mentén méri a nézők motivációit. A készítők a skála hat faktorát a következőképpen határozták meg: Társas kapcsolatok, Teljesítmény, Önbecsülés, Izgalomkeresés, Kikapcsolódás/Elszabadulás, Esztétikum/Szépség (KAJOS et al. 2017).

Így tehát ezt a skálát alkalmasnak találtam a DVSC labdarúgó szakosztályának helyszíni szurkolóinak, azon belül is a bérlettel rendelkezők fogyasztási motivációinak mérésére. 


\section{ANYAG ÉS MÓDSZER}

A bevezetésben felsorolt célok eléréséhez a kérdőíves felmérés módszerét választottuk, mivel ezt találtuk a legalkalmasabbnak a DVSC labdarúgó csapat bérlettel rendelkező szurkolóinak összetételének és motivációinak vizsgálatára.

A nézőtéri sportfogyasztók jellemzőinek és motivációinak tanulmányozása érdekében, és a megfelelő szakirodalmi források feldolgozása alapján elkészítettünk egy kérdőívet, mely a szükséges szociodemográfiai kérdéseken túl mérkőzéslátogatási szokásokkal, létesítménnyel és szolgáltatásokkal, illetve belépőkkel, jegyárakkal kapcsolatos kérdéseket tartalmaz. Ezek mellett rákérdeztünk a mérkőzéslátogatások, és azok csökkenésének lehetséges okaira. Továbbá beépítettük a kérdőívbe a Kajos Attila, Prisztóka Gyöngyvér és Paic Róbert által, 2017-ben validált SPEEDE-H skálát.

Fontosnak tapasztalat lehet, a személyes megkérdezés, ezért 2019 novemberében és decemberében összesen három alkalommal, a DVSC labdarúgó csapatának hazai mérkőzései előtt összesen 13 emberrel sikerült személyesen kitöltetni a kérdőívet. A megkérdezések során a szurkolók hozzáállása rendkívül pozitív és segítőkész volt, szívesen osztották meg véleményüket a klubbal és a hazai alacsony nézőszámok problémájával kapcsolatban.

A kérdőívet a továbbiakban interneten megosztottuk, így összesen 49 fős lett a minta. A válaszadók között 46 férfi és 3 nő volt, tehát a kitöltők 94\%-a férfi, 6\%-a nő.

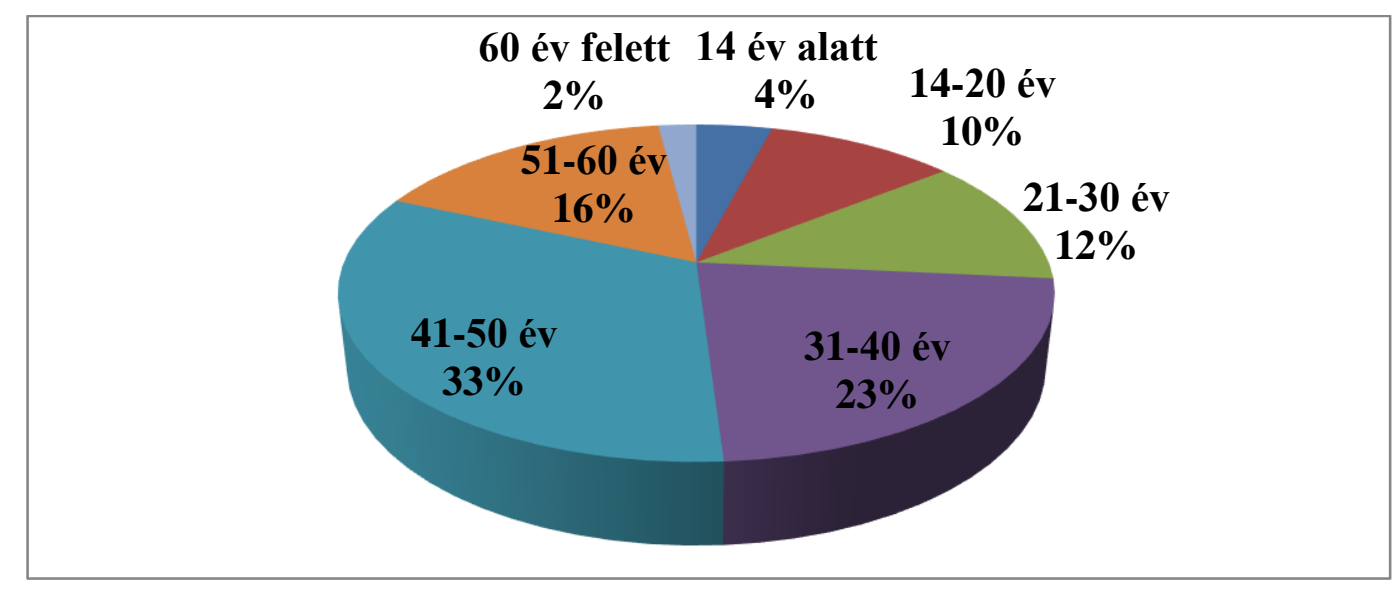

1.ábra: A minta életkor szerinti megoszlása

Forrás: Saját szerkesztés, 2020

Az életkor alapján, ahogyan az 1. ábráról leolvasható, legnagyobb arányban a 41-50 év közöttiek (33\%) szerepelnek. Őket követi sorrendben a 31-40 éves korosztály (23\%), majd az 51-60 évesek (16\%), utánuk közel azonos százalékban a 21-30 (12\%) és 14-20 
év köztiek (10\%) következnek, a 14 év alattiak (4\%) és a 60 évnél idősebbek (2\%) az utolsók a sorban..

Családi állapot tekintetében egyedül 24,5\%-uk él, 1 fővel 20,4\%, 2-4 fővel 49\%, illetve 5 vagy annál több fővel 6,1\% osztozik közös háztartáson. A minta legmagasabb iskolai végzettség szerinti megoszlása a következőképpen alakul: kevesebb mint nyolc általánosa 10,2\%-nak van, nyolc általánossal 6,1\%, szakiskola/szakmunkás képesítéssel 4,1\%, érettségivel 44,9\%, főiskolai végzettséggel 12,2\% rendelkezik, míg az egyetemet végzettek aránya $22,4 \%$.

Továbbá havi jövedelmük nagyságára is rákérdeztünk, az erre érkezett válaszok alapján a következő a sorrend az egyes kategóriák között: 1. 200001 - 300000 Ft (24,4\%), 2. 300001 - $400000 \mathrm{Ft}(19,5 \%), 3.100001$ - $200000 \mathrm{Ft}(17,1 \%), 4.100000 \mathrm{Ft}$ alatt (9,8\%), 5. $400001-500000 \mathrm{Ft}(9,8 \%), 6.500001-1000000 \mathrm{Ft}(9,8 \%), 7.1000000 \mathrm{Ftfelett}(2,4 \%)$.

\section{EREDMÉNYEK}

Először arra kerestük a választ, hogy a válaszolók mióta látogatják a DVSC labdarúgócsapatának hazai mérkőzéseit. Az eredmények azt mutatják, hogy az előző szezon, azaz a 2018/19-es idény óta csupán 2\%-uk jár, 2-4 éve 8\%-uk, 5-10 éve 12\%-uk, 10-20 éve 27\%-uk, 51\%-uk több mint 20 éve tekinti meg a csapat hazai összecsapásait. Ezekből az adatokból levonható az a következtetés, hogy minél régebb óta jár valaki mérkőzésekre, annál nagyobb a valószínűsége annak, hogy bérlettel rendelkezik.

Egy szezonon belül a megkérdezettek 67\%-a minden mérkőzésre (néhány kivételével), 20\%-a 10-nél többre, 6-6 \%-uk 5 - 10 közötti, illetve 5-nél kevesebb mérkőzésre látogat ki.

A válaszadók 12,2\%-a úgy nyilatkozott, hogy rendszeresen, 63\%-a néhány alkalommal, 25\%-a pedig nem jelenik meg a vendég lelátókon, az idegenbeli meccseken.

A kitöltők életüknek átlagosan 13. évében látták először helyszínen a DVSC mérkőzését. Az első mérkőzésére a minta 55\%-át szülei vitték el, 18\%-át barátaik, 23\% a sport/labdarúgás szeretete miatt, a maradék 4\% pedig egyéb okból látogatott ki. A média motiváló erejét viszont senki sem jelölte meg. 


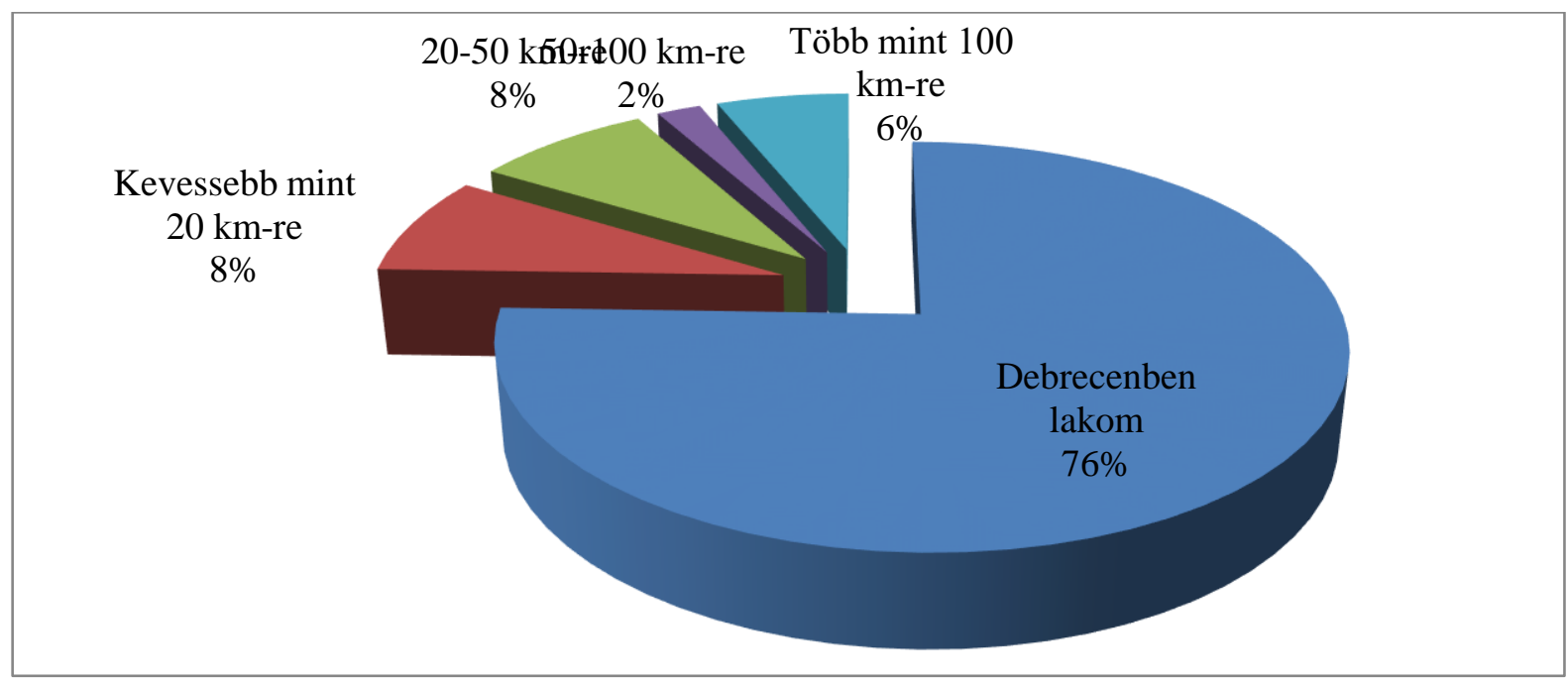

2. ábra: A válaszok megoszlása a lakóhely Debrecentől való távolsága alapján Forrás: saját szerkesztés, 2020

A megkérdezettek nagy többsége a 2. ábra alapján Debrecenben és vonzáskörzetében él, de előfordulnak olyanok, akik nagyobb távokat is megtesznek azért, hogy a helyszínen lehessenek (a minta 6\%-a 100 km-től messzebbről érkezik a mérkőzésekre).

A kitöltők legnagyobb gyakorisággal barátaikkal látogatják a DVSC mérkőzéseit, valamivel kevesebben rokonaikkal, míg mindössze páran munkatársaikkal.

A Loki összecsapásaira a minta közel 60\%-a saját gépjárműjével; gyalog 16\%; barátok, ismerősök, családtagok gépjárműjével 10\%; a DKV járataival 8\%; kerékpárral 6\% érkezik a színtérre. Két válaszlehetőség, a motorkerékpár és a vonat, távolsági busz (és DKV járatai) nem kapott egyetlen jelölést sem. Ebből fakadóan arra a következtetésre lehet jutni, hogy a klub intézkedésének - a mérkőzések napján a DKV járatain való ingyenes utazási lehetőség - ellenére a legtöbben mégis gépjárművel közelítik meg a Nagyerdei Stadiont.

Ehhez kapcsolódóan arra is fény derült, hogy a parkolási opciókat tekintve 63\%-os az elégedettség, míg 37\% kifogásolja a stadion körüli megállási lehetőségeket.

A kitöltők 43\%-a saját bevallása szerint 15 percnél kevesebb idő alatt ér ki a stadionba a mérkőzések napján, 39\%-nak 16-30 perc, 14\%-nak 31-60 perc a kijutási ideje, míg 2-2\% a 61-90 percet és a 90 percnél többet utazók aránya, ebből is látszik, hogy vannak olyan bérletesek, akik a nagyobb távolságok ellenére is megjelennek a nézőtéren. 
1. táblázat: A válaszadók aránya a Nagyerdei Stadion szektorai alapján

\begin{tabular}{|l|r|r|}
\hline Szektor megnevezése & $\begin{array}{l}\text { A szektorban helyet foglalók } \\
\text { Száma }\end{array}$ & $\begin{array}{l}\text { Százalékos } \\
\text { megoszlás }\end{array}$ \\
\hline A szektor & 7 & $14 \%$ \\
\hline $\begin{array}{l}\text { B szektor (B-közép } \\
\text { kivételével) }\end{array}$ & 14 & $29 \%$ \\
\hline B- közép (B5, B6 szektorok) & 12 & $24 \%$ \\
\hline C szektor & 4 & $8 \%$ \\
\hline D szektor & 1 & $2 \%$ \\
\hline VIP & 11 & $22 \%$ \\
\hline
\end{tabular}

Forrás: saját szerkesztés, 2020

A felvett adatok alapján az 1. táblázat azt mutatja, hogy a megkérdezettek stadionon belül hol szoktak helyet foglalni.

A jegyek és bérletek árával kapcsolatban 96\% elégedett volt, és csupán két válaszadó alany, azaz 4\% jelezte elégedetlenségét. Ez az adat azt is jól tükrözi, hogy a magyar bajnokságon belül a DVSC kimondottan kedvezően határozza meg belépőinek árait. A legnagyobb összeg, amit a válaszadók átlagosan kifizetnének egy jegyért, ami arra a helyre szól, ahova általában szoktak ülni a beérkezett adatokat átlagolása alapján, a maximum 5000 Ft lett.

A mérkőzések helyszíni megtekintésének elképzelhető okaként a kitöltők több válaszlehetőséget is megjelölhettek. A felvett adatokból kiderül, hogy az első helyen a labdarúgás szeretete áll, második helyen holtversenyben a jó társaság és a jó hangulat szerepel, míg a harmadik legtöbb voksot az azonosulás a csapattal kapta. Ennélfogva a DVSC megkérdezett bérleteseinek nem csupán maga a labdarúgás jelent indítékot, hanem a mérkőzéslátogatásaikat övező körülmények, azaz a társaság és a hangulat is befolyásolja a fogyasztást, ezek mellett pedig erőteljes hatása van a csapattal való azonosulásnak, azaz az ahhoz való kötődésnek, így kiemelten fontos lehet ezt a fajta szurkoló-játékos, szurkoló-csapat kapcsolatot fenntartani, a két fél közötti kommunikációt erősíteni és minél szorosabb köteléket kialakítani. 
2. táblázat: A SPEEDE-H skálával történő mérés eredményei

\begin{tabular}{|c|c|c|}
\hline $\begin{array}{l}\text { A SPEEDE-H skála faktorai és a hozzájuk tartozó } \\
\text { állítások }\end{array}$ & $\begin{array}{l}\text { A válaszok } \\
\text { átlagai } \\
\text { állításonk } \\
\text { ént }\end{array}$ & $\begin{array}{l}\text { A válaszok } \\
\text { átlagai } \\
\text { faktoronké } \\
\text { nt }\end{array}$ \\
\hline \multirow{2}{*}{$\begin{array}{l}\text { Társas kapcsolatok } \\
\text { Szeretem, hogy a mérkőzésen való részvétel lehetőséget } \\
\text { teremt az ismerkedésre. } \\
\text { Szeretem, hogy a mérkőzésen való részvétel lehetőséget } \\
\text { teremt rá, hogy beszélgessek másokkal. }\end{array}$} & 3,29 & \multirow{2}{*}{3,61} \\
\hline & 3,94 & \\
\hline \multirow{2}{*}{$\begin{array}{l}\text { Teljesítmény } \\
\text { A mérkőzést a játékosok által nyújtott teljesítmény miatt } \\
\text { szeretem nézni. } \\
\text { A mérkőzést a játékosok képességei/készségei miatt } \\
\text { nézem. }\end{array}$} & 3 & \multirow[t]{2}{*}{2,89} \\
\hline & 2,78 & \\
\hline \multirow{3}{*}{$\begin{array}{l}\text { Önbecsülés } \\
\text { Ha a csapat nyer, én is nyerek. } \\
\text { A csapat győzelme sikerélményt nyújt számomra. }\end{array}$} & & \multirow{3}{*}{4,47} \\
\hline & 4,45 & \\
\hline & 4,49 & \\
\hline \multirow{3}{*}{$\begin{array}{l}\text { Izgalomkeresés } \\
\text { Szeretem a mérkőzések izgalmát. } \\
\text { Nagyon izgalmasnak találok egy mérkőzést. }\end{array}$} & & \multirow{3}{*}{4,13} \\
\hline & 4,55 & \\
\hline & 3,71 & \\
\hline \multirow{2}{*}{$\begin{array}{l}\text { Kikapcsolódás/Elszabadulás } \\
\text { A mérkőzésen való részvétel segít elmenekülni az } \\
\text { életemmel kapcsolatos feszültségek elől. } \\
\text { A mérkőzésen való részvétel segít elszakadni a } \\
\text { mindennapi élet rutinjától. }\end{array}$} & 2,79 & \multirow[b]{2}{*}{3,17} \\
\hline & 3,54 & \\
\hline \multirow{3}{*}{$\begin{array}{l}\text { Esztétikum/Szépség } \\
\text { Szeretem a játék/sportág eleganciáját. } \\
\text { Szeretem a sportág szépségét. }\end{array}$} & & \multirow{3}{*}{4,03} \\
\hline & 3,84 & \\
\hline & & \\
\hline
\end{tabular}

Forrás: saját szerkesztés, 2020

A nézőtéri sportfogyasztás motivációinak mérésére, a SPEEDE-H skálát alkalmaztuk, ahol a válaszadóknak el kellett dönteniük, hogy a 6 faktorból álló SPEEDE-H skála állításai mennyire igazak rájuk egy öt fokozatú Likert-skálán, ahol az „1” az egyáltalán nem, míg az „5” a teljes mértékben igazat jelentette, a mérés eredményeit a 2. táblázat tartalmazza. Az Önbecsülés 4,47-es értékével tekinthető az elsőszámú motivációs faktornak, tehát a megkérdezettek nézőtéri sportfogyasztását a csapat győzelmének és sikerének saját sikerként történő megélése ösztönzi leginkább. Az itemeket tekintve a legerősebb motivációs tényező az Izgalomkeresés faktoron belül található, mégpedig a „Szeretem a 
mérkőzések izgalmát" állítás volt, 4,55-ös értékkel. Ennek értelmében a mérkőzések (várható) izgalma az, amely elsődlegesen motiválja őket, viszont a faktor másik iteme már jóval alacsonyabb, 3,71-es átlagot produkált, szóval voltaképpen az, hogy nagyon izgalmasnak találnak egy mérkőzést, már kevésbé igaz rájuk. Eképpen annak ellenére, miszerint nem különösebben találják a DVSC mérkőzéseit izgalmasnak, mégis a bizonytalan végkimenetelből, a meccsekből adódó stressz és izgalom az, ami a legnagyobb motivációja a bérletesek körében a helyszíni nézőtéri sportfogyasztásnak Debrecenben.

A legkisebb motivációt a skála Teljesítmény faktora adja, ami mentén arra a következtetésre lehet jutni, hogy a DVSC bérleteseit a játékosok képességei és készségei, valamint az általuk nyújtott teljesítmény befolyásolja legkevésbé fogyasztási döntésük meghozatalában.

Bár legtöbben úgy nyilatkoztak, hogy nem változtak a mérkőzéslátogatási szokásaik, azok, akik bevallásuk szerint a korábbiakhoz képest kevesebb alkalommal tekintenek meg helyszínen mérkőzéseket, az alacsony játékszínvonalat jelölték meg elsődleges okként. Második meghatározó ok a hangulat hiánya, harmadik helyen holtversenyben az MLSZ korábbi, nem szurkolóbarát intézkedései (BALOGH-BÁCSNÉ, 2019) és a gyengébb szereplés az elmúlt években elnevezésű okok állnak. Következésképp azok a bérletesek, akik kevesebbszer tekintenek meg helyszínen hazai mérkőzéseket, ennek okát elsősorban a rosszabb játékszínvonal és a jó teljesítmény hiányaként határozták meg.

A mintának közel 100\%-a volt elégedett a helyszínül szolgáló sportlétesítménnyel, azaz a Nagyerdei Stadionnal. Ugyanakkor a mérkőzések ideje alatt nyújtott szolgáltatások vonatkozásában már más az arány, bár 59\%-uk az elégedett volt ezzel, 41\%-uk nem találta kifogástalannak a szolgáltatásokat, ezen véleményüket pedig a lassú kiszolgálással indokolták.

A kitöltők legnagyobb többsége a DVSC közönségének növelését a játékosok és a szurkolók közötti kapcsolat erősítésével oldaná meg. Többször említették, hogy szívesen találkoznának a pályán kívül is a csapat tagjaival, ami erősíthetné a kötődést a klub és a szurkolók között, a bérlettel rendelkezők száma pedig emelkedhetne. Így kialakulhatna egyfajta tisztelet és érdeklődés a játékosok és teljesítményük iránt, a szurkolók pedig fontosnak éreznék magukat, ezért egy esetlegesen előforduló rosszabb játékminőség és széria esetén is biztosítható lenne, hogy a lelátón helyet foglalók száma ne csökkenjen.

\section{KÖVETKEZTETÉSEK ÉS JAVASLATOK}

Az eredményekből arra lehet következtethetni, hogy a DVSC hazai labdarúgó mérkőzéseire állandó belépővel rendelkezők legnagyobb többségében férfiak, több mint felük 31 és 50 év közötti és közös háztartásban él 2-4 fővel, tehát az átlagbérletest középkorú, családos férfiként lehetne meghatározni. 
Átlagosan 13 éves korukban látták életükben először a DVSC-t élőben, ahová túlnyomórészt szüleikkel mentek el, így megállapítható, hogy a szülők döntően meghatározhatják gyerekeik későbbi mérkőzéslátogatási szokásait, főleg ha ez fiatal korukban történik meg.

Mivel a minta majdnem háromnegyede szinte az összes hazai mérkőzésen részt vesz nézőként, ezért a bérletesek gyarapításának megcélzása fontos lépés a rendszeres nézőtéri sportfogyasztás és a stabil nézőszámok eléréséhez. Ennek megvalósítására a klub az egy szezonra szóló belépők magyar viszonylatban is kedvező áraival és a hozzájuk tartozó kedvezményekkel már megtette első lépéseit.

Bár a klub a DKV-val való együttműködéssel támogatja a belépővel rendelkezők helyszínre való kijutását, illetve tehermentesíteni próbálja a Nagyerdei Stadion környékét, az eredmények azt mutatják, hogy a nézők nagy többségben ennek ellenére továbbra is gépjárművel közlekednek, a válaszok alapján pedig szükség lehet a parkolási lehetőségek bővítésére.

Az elsőszámú motivációs faktor a mérkőzések helyszíni megtekintéséhez az Önbecsülés faktor volt, illetőleg a meccstől való távolmaradás legfőbb indoka az alacsony játékszínvonal volt. Ebből kiderül, hogy a rosszabb szereplést és gyengébb teljesítményt saját kudarcukként élhetik meg a szurkolók, mely érzés újbóli előfordulásának elkerülése miatt csökkenhet a mérkőzéslátogatásaik száma, így ezzel is magyarázhatóak a nézőtéri üres helyek.

A bérlettel rendelkezők között a fiatal korosztály, azaz a 20 év alattiak kis arányban jelentek meg, így ezen fogyasztók megnyerése kifejezetten ajánlott, olyan okból is, hogy ők a következő évtizedekben is biztos közönséget jelenthetnek a DVSC-nek.

Természetesen a bérletszámok növelésének egyik feltétele a klub iránti hűség és kötődés kialakítása, mely a publikum és a csapat közötti szoros kapcsolat kiépítésével kivitelezhetnek.

A publikáció elkészítését az EFOP-3.6.1-16-2016-00022 „Debrecen Venture Catapult Program” projekt támogatta. A projekt az Európai Unió támogatásával, az Európai Szociális Alap társfinanszírozásával valósult meg. 


\section{IRODALOMJEGYZÉK}

Balogh, R., Bácsné, Bába É. (2019). Sportszövetségi intézkedések attitűdvizsgálata. Acta Carolus Robertus, 9, (1), 23-33.

Balogh, R., Bácsné, Bába É. (2019a). Az MSSC szurkolói motivációs skála adaptálása egyetemi hallgatók körében. Studia Mundi - Economica, 6, (1), 3-10.

Balogh, R., Dajnoki, K., \& Bácsné, Bába É. (2019b). Miért beteg a magyar futball még mindig? - a magyar labdarúgás játékos piacának jellemzése. Jelenkori Társadalmi És Gazdasági Folyamatok, 13, (3-4), 105-117.

Balogh, R., Molnár, A., Müller, A., Szabados, Gy. N., \& Bácsné, Bába É. (2019c). A passzív sportfogyasztás vizsgálatának tapasztalataiból. Acta Carolus Robertus, 9, (1), 35-48.

Bácsné, Bába É., Balogh, R., Bács, B. A., Molnár, A., Fenyves, V., \& Müller, A. (2019). A passzív sportfogyasztás motivációinak vizsgálata nemek tükrében. Economica (Szolnok,) 10, (1), 30-35.

Clarke, J. (1978). Football and working class fans. In R. Ingham, S. Hall, J. Clarke, P. Mann, and J. Donovan (Eds.). Football hooliganism: The wider context. London: Inter-action Imprint.

Dvsc.hu (2020). Szerdáig kaphatóak a tavaszi bérletek. https://www.dvsc.hu/kiemelthirek/szerdaig-kaphatok-a-tavaszi-berletek letöltés dátuma: 2020. 02.10.

Hoffmann I. (2000). Sportmarketing. Bagolyvár Könyvkiadó, Budapest, ISBN 9639197645

Kajos A., Prisztóka Gy., \& Paic Á. (2017). A nézőtéri sportfogyasztás motivációit mérő, magyar nyelvű „speede-h” skála validációja és néhány eredménye. Vezetéstudomány / Budapest Management Review, XLVIII, (10).

Lewis, M. (2001). Franchise relocation and fan allegiance. Journal of Sport and Social Issues, 25, (1), 6-19.

LokomotívBlog (2019). NB I Bérletárak - Nyúlj mélyen a zsebedbe?. http://lokomotivblog.hu/archives/2019/07/31/nb-i-berletarak-nyulj-melyen-azsebedbe/ letöltés dátuma: 2020. 02. 19.

Magyarfutball.hu (2020). https://www.magyarfutball.hu/hu/merkozesek/bajnoki merkozesek/nb i 
Vol 3, No 1 (2020): Stadium -Hungarian Journal of Sport Sciences

https://doi.org/10.36439/SHJS/2020/1/5457

letöltés dátuma: 2020.01.05.

Mullin, B. J., Hardy, S., \& Sutton, W. A. (2000). Sport marketing (2ed.). Human Kinetics Publishers, USA.

Neulinger Á. (2007). Társas környezet és sportfogyasztás. A folyamatos megerősítést igénylő tanult fogyasztás. Ph.D.-értekezés, Budapest

Shank, M. D. (2002). Sportmarketing, Prentice Hall.

Smith, A., Stewart, B. (1999). Sports management: A guide to professional practice. Sydney, Australia: Allen and Unwin.

Stewart, B., Smith, A. C. T., c Nicholson, M. (2003). Sport consumer typologies: A critical review. Sport Marketing Quarterly, 12, (4), 206-216.

Szabó Á. (2009). A (szabadidő)sport alapfogalmai és kutatott területei. 115. sz. Műhelytanulmány, Budapest ISSN 1786-3031 